\title{
Effectiveness of Different Pedagogy in Management Studies
}

\author{
Seema Sunuwar*
}

\begin{abstract}
The main purpose of this study is to determine perception of the different pedagogy methods among undergraduate students and faculties in a management college. The study is a primary research conducted using questionnaire and interview method at Nepal College of Management, Nepal. The result of the study shows that the students found lecture using power point presentations as the most effective one followed by case studies methods and audio video teaching, whereas lecture using power point presentations followed by audio video based teaching as the most easy to understand as well as recall. The faculties'opined case based study and brainstorming methods as the most effective method of teaching. The study also indicates that there is significant relationship between ease of understanding the pedagogy and its effectiveness as well as between ease to recall the lessons learnt using the pedagogy and its effectiveness.
\end{abstract}

Key words: Pedagogy, Management Education, Student, Faculty, Perception

\footnotetext{
*Faculty Member, Nepal College of Management, Kathmandu University, corresponding Email: sunuwarseema@gmail.com
} 


\section{Introduction}

Management studies are there for developing future managers, professionals, innovators and entrepreneurs who will be organizing, planning, controlling, and directing their organization's resources in order to achieve the organization's objectives. Things these students learn and how they were taught will help determine and shape their future directly or indirectly. Knowledge imparted on the students depends upon the knowledge acquired by the teacher, his/her way of presentation skills as well as the many teaching pedagogies applied by the teacher.

Oxford Dictionary defines Pedagogy as "The method and practice of teaching, especially as an academic subject or theoretical concept". Watkins and Mortimer (1999) assert that pedagogy is any conscious activity by one person designed to enhance the learning of another. The National Board for Professional Teaching Standards defines pedagogy as: "Content pedagogy refers to the pedagogical (teaching) skills teachers use to impart the specialized knowledge /content of their subject area(s). Effective teachers display a wide range of skills and abilities that lead to creating a learning environment where all students feel comfortable and are sure that they can succeed both academically and personally. This complex combination of skills and abilities is integrated in the professional teaching standards that also include essential knowledge, dispositions, and commitments that allow educators to practice at a high level."

Competition is in its highest form today, be it in education or the job market sector. Students these days, before getting admitted to any college or university, will seek information regarding the faculties and teaching methods applied in that particular college. So, it will be a smart move for the colleges/universities to get updated about the local as well as global market trend of different innovative and effective pedagogies.

The main objective of this study is to investigate perception of the different pedagogy methods among undergraduate students and faculties of Nepal College of Management, Nepal. And also to compare the various pedagogies on parameters such as ease to understand and recall.

Specifically, the study aims at finding answers to the following questions.

1. Which is the best pedagogy as perceived by the under-graduate students and faculties? 
2. Is there significant relationship between the ease of understanding the pedagogy and effectiveness of the pedagogy used?

3. Is there significant relationship between ease of recalling the lessons learnt using the pedagogy and the effectiveness of the pedagogy used?

4. What do students think should be done by faculties to make the learning more effective?

5. What do faculties think should be done for better learning of the students?

6. What are the hindrances faced by faculties which cause them to not use an innovative pedagogy?

The remainder of this paper is presented as follows: Section II includes the literature review on pedagogy in relation with today's business education. Section III describes the research methodology, nature and sources of data. Section IV presents the results and summarizes the conclusion.

\section{Literature Review}

With changing time, even teaching pedagogies are getting technologically advanced and the requirement for the teachers to be technically savvy is a must in order to run the class and course effectively. Many empirical studies were found on the effectiveness of different pedagogies in the management studies, but the same is not found in the context of Nepalese Management Colleges and Business Schools.

Narayandas, Rangan and Zaltman (1998) have discussed in their study on the pedagogical methods in business marketing education and concluded that the educational institutions have to deliver high quality of conceptual and contextual knowledge through well-structured syllabi and teaching.

Kozma (2003) looked at how classrooms worldwide are using technology to change the practices of teachers and students. It was found that teachers in many countries are beginning to use information and communications technologies (ICT) to help change classroom teaching and learning, and are integrating technology into the curriculum. The study showed that when teachers go beyond the basic practices and use technology to plan and prepare instruction and collaborate with outside actors, and when students also use technology to conduct research projects, analyze data, solve problems, design products, and assess their own work, students are 
more likely to develop new ICT, problem solving, information management, collaboration, and communication skills.

NBEA (2004) suggested that business educators have to consider integrating their curriculum with business content, real issues of the industry and on the other hand offering few courses based on global business.

Whitby (2007) stated in his study that the old pedagogies persisting into the $21^{\text {st }}$ century are no longer relevant. In order to embrace the new opportunities of schooling taking place in both a physical and virtual learning space, 21 st century pedagogy is needed- a paradigm which reflects a bold and creative commitment to relevance and quality learning and teaching. There are many forces seeking to re-shape the future of schooling. Essential contributors to this inevitable process must be the teachers and the learning communities to which they belong.

Ginsburg (2010) in his study found that the scholarly literature as well as the policy documents of international organizations and national government has increasingly championed studentcentered, active-learning pedagogies as a key element in improving the quality of education. Also, the students prefer strategies promoting active learning to traditional lectures.

Goyal and Parekh (2012) conducted a study on the perception of two very important stakeholders student and faculty members towards various teaching pedagogies been used in management institutions. The research shows that faculty members found power-point presentations to the easiest, followed closely by assignments and lectures. On the other hand, students found projects to be the most effective in evaluation followed by case study and exercises.

Raman (2013) on her study "Innovative Pedagogical methods for Imparting Management Education to Indian Students" compared and evaluated the traditional teaching methods with the other emerging multimedia based learning methods. The study revealed that the main objectives of any learning method should be to retain the interest of the learner throughout the learning process and to enhance retention for the learner. It was concluded that interactive teaching method is the need of today's generation and this changing role of education is inevitable with the introduction of multimedia technology and the spawning of a technology-savvy generation of youths. 
Kumar (2014) stated that the Indian Business Schools have to change their pedagogical methods as per the demands of a fast-changing business Environment and produce future managers equipped with all the skills required to articulate the best possible strategies. The teaching methods should focus more deeply on leadership, team work, communication skills, and on how to prepare students to play a critical result oriented role in terms of changing an organization for the better.

According to Nawaz and Gomes (2014), business schools have to implement and practice their pedagogy by considering the pedagogical knowledge, content knowledge, curriculum knowledge and faculty knowledge, with integration of creativity, critical thinking, communication and collaboration.

\section{Research Methodology}

\section{Nature and Sources of Data}

The study is based on primary data. The primary data were collected by using questionnaire survey method. From the questionnaire survey distributed to 200 students from different levels, only 134 responses were received. Faculties from various backgrounds like General Management (Marketing, Human Resource Management, Sales Management, and Business Environment), Finance and Economics were asked about the pedagogies they use while teaching and if they would like to use innovative pedagogies in future. The respondents were aware about most of the pedagogies though not all were used by them (simulation, computer simulation, games and role play).

\section{Pedagogical Methodologies Taken into Consideration for the Study}

a) Audio-Video Based Teaching: It is an instruction method where particular attention is paid to the audio and visual presentation of the material with the goal of improving comprehension and retention.

b) Brainstorming/ Group Discussion: A process for generating multiple ideas/options in which judgment is suspended until a maximum number of ideas has been generated. Following generation of ideas, options are typically analyzed, a best solution identified, and a plan of action developed. 
c) Case-Based Method: Case-based teaching is an active learning strategy in which students read and discuss complex, real-life scenarios that call on their analytical thinking skills and decision-making. Small groups of 5-10 address case-based tasks, exchanging points of view while working through a problem-solving process.

d) Computer Simulation: Computer simulation for educational purposes is a part of what is called computer-assisted learning.

e) Demonstration: Performing an activity so that learners can observe how it is done in order to help prepare learner to transfer theory to practical application.

f) Dictation: Dictation refers to a teacher reading some text aloud so that the listeners/ students can write down what is being said.

g) Field Visit: Field visits are educational trips to sites where students have the opportunity to observe their chosen subject outside of a classroom setting.

h) Game: Game is used to bring competition, participation, drills, and feedback into the learning experience as a motivator and opportunity for application of principles.

i) Lecture/Presentation: The lecture method is a teaching method where the instructor acts as the primary information giver. The instructor typically stands in front of the students and may use a visual aid, such as a PowerPoint presentation, whiteboard, book or handout.

j) Project Method: The project method is a medium of instruction where students has to apply the skills and knowledge they had learned in the course of their studies to problems they had to solve as practitioners of their field. It is an experience-centered strategy related to real life-situation.

k) Quiz: Quick quizzes can help teachers assess the effectiveness of their instruction, as well as student understanding of the concepts taught. The primary function of these frequent classroom quizzes is to evaluate student learning in relation to the teachers' instructional methods.

1) Role Play: One or more participants adopt a specified role and try to behave in ways characteristics of a person in that role. In business education, it often revolves around a specified company facing some problems scenario.

m) Simulation: A simulation is a form of experiential learning and training, which develops the ability in an individual regarding problem solving behavior. It has been defined as a role playing strongly in which learners perform in an artificially created environment. 


\section{Theoretical Framework}

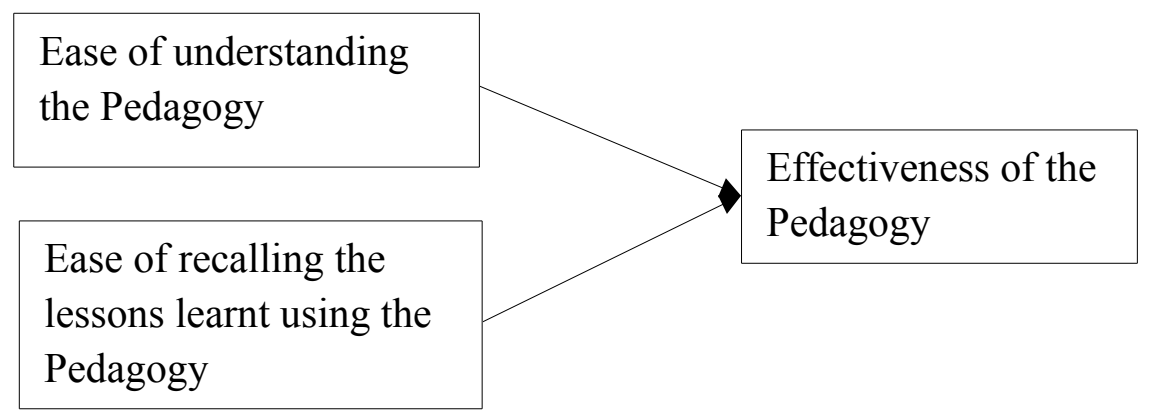

Figure 1: Theoretical Framework

The independent variables of this study are ease of understanding the pedagogy and ease of recalling the lessons learnt using various pedagogies. The dependent variable is effectiveness of the pedagogy.

\section{Research Hypotheses}

H1: Ease of understanding the pedagogy technique has significant relationship with the effectiveness of that pedagogy.

$\mathrm{H} 2$ : Ease of recalling the lessons learnt using the pedagogy has significant relationship with the effectiveness of that pedagogy. 


\section{Results and Conclusion}

\section{Students Perception on Different Pedagogies}

From Table 1, it is clear that majority of the students find lecture using power point presentations as the most effective one followed by case studies and audio video teaching methods. On the other hand, they find demonstration, field visit, dictating notes and brainstorming (group discussion) as the most ineffective pedagogies.

Table 1

Students' Perception on the Effectiveness of Pedagogies

\begin{tabular}{|c|c|c|c|c|c|c|c|c|c|c|c|c|}
\hline \multirow{3}{*}{$\begin{array}{c}\text { Types of } \\
\text { Pedagogy }\end{array}$} & \multicolumn{10}{|c|}{ Students' Perception on Effectiveness of Different Pedagogies } & \multirow{3}{*}{$\begin{array}{c}\text { Weighted } \\
\text { Mean }\end{array}$} & \multirow{3}{*}{ Rank } \\
\hline & \multicolumn{2}{|c|}{$\begin{array}{c}\text { Most Effective } \\
\text { (5) }\end{array}$} & \multicolumn{2}{|c|}{$\begin{array}{c}\text { Effective } \\
\text { (4) }\end{array}$} & \multicolumn{2}{|c|}{$\begin{array}{c}\text { Neutral } \\
\text { (3) }\end{array}$} & \multicolumn{2}{|c|}{ Ineffective(2) } & \multicolumn{2}{|c|}{$\begin{array}{c}\text { Most } \\
\text { Ineffective(1) }\end{array}$} & & \\
\hline & $\begin{array}{l}\text { Freq } \\
(\mathrm{F})\end{array}$ & $\%$ & $\begin{array}{l}\text { Freq } \\
(\mathrm{F})\end{array}$ & $\%$ & $\begin{array}{l}\text { Freq } \\
(\mathrm{F})\end{array}$ & $\%$ & $\begin{array}{l}\text { Freq } \\
(\mathrm{F})\end{array}$ & $\%$ & $\begin{array}{c}\text { Freq } \\
(\mathrm{F})\end{array}$ & $\%$ & & \\
\hline $\begin{array}{c}\text { Lecture } \\
\text { Referring Ppt. }\end{array}$ & 41 & 30.6 & 31 & 23.1 & 27 & 20.1 & 10 & 7.5 & 6 & 4.5 & 3.25 & 1 \\
\hline Case Studies & 16 & 11.9 & 22 & 16.4 & 29 & 21.6 & 11 & 8.2 & 7 & 5.2 & 2.12 & 2 \\
\hline $\begin{array}{c}\text { Audio-Video } \\
\text { Based Teaching }\end{array}$ & 25 & 18.7 & 22 & 16.4 & 9 & 6.7 & 10 & 7.5 & 7 & 5.2 & 1.99 & 3 \\
\hline Project Work & 12 & 9 & 16 & 11.9 & 18 & 13.4 & 8 & 6 & 8 & 6 & 1.51 & 4 \\
\hline Quiz & 2 & 1.5 & 11 & 8.2 & 14 & 10.4 & 17 & 12.7 & 29 & 21.6 & 1.19 & 5 \\
\hline $\begin{array}{c}\text { Lecture } \\
\text { Referring Book }\end{array}$ & 12 & 9 & 7 & 5.2 & 6 & 4.5 & 16 & 11.9 & 13 & 9.7 & 1.13 & 6 \\
\hline Brainstorming & 9 & 6.7 & 6 & 4.5 & 8 & 6 & 4 & 3 & 13 & 9.7 & 0.85 & 7 \\
\hline Dictating Notes & 7 & 5.2 & 10 & 7.5 & 4 & 3 & 3 & 2.2 & 11 & 8.2 & 0.78 & 8 \\
\hline Field Visit & 2 & 1.5 & 6 & 4.5 & 3 & 2.2 & 4 & 3 & 4 & 3 & 0.41 & 9 \\
\hline Demonstration & 2 & 1.5 & 1 & 0.7 & 3 & 2.2 & 0 & 0 & 1 & 0.7 & 0.18 & 10 \\
\hline Total & 128 & 95.6 & 132 & 98.4 & 121 & 90.1 & 83 & 62 & 99 & 73.8 & & \\
\hline
\end{tabular}

From Table 2, it is seen that majority of the students find lectures using power point presentations as the most easy to understand, followed by audio video teaching method and case studies while, they find demonstration, field visit and brainstorming (group discussion) as the most difficult to understand pedagogies. 
Table 2

Students' Perception on Ease of Understanding the Pedagogies

\begin{tabular}{|c|c|c|c|c|c|c|c|c|c|c|c|c|}
\hline \multirow{3}{*}{$\begin{array}{l}\text { Types of } \\
\text { Pedagogy }\end{array}$} & \multicolumn{10}{|c|}{ Students' Perception on Ease of Understanding of Different Pedagogies } & \multirow{3}{*}{$\begin{array}{l}\text { Weighted } \\
\text { Mean }\end{array}$} & \multirow{3}{*}{ Rank } \\
\hline & \multicolumn{2}{|c|}{ Most Easy (5) } & \multicolumn{2}{|c|}{$\begin{array}{l}\text { Moderately } \\
\text { Easy(4) }\end{array}$} & \multicolumn{2}{|c|}{ Easy(3) } & \multicolumn{2}{|c|}{ Difficult(2) } & \multicolumn{2}{|c|}{$\begin{array}{l}\text { Most } \\
\text { Difficult(1) }\end{array}$} & & \\
\hline & $\begin{array}{l}\text { Freq } \\
(\mathrm{F})\end{array}$ & $\%$ & $\begin{array}{l}\text { Freq } \\
(\mathrm{F})\end{array}$ & $\%$ & $\begin{array}{l}\text { Freq } \\
(\mathrm{F})\end{array}$ & $\%$ & $\begin{array}{l}\text { Freq } \\
(\mathrm{F})\end{array}$ & $\%$ & $\begin{array}{c}\text { Freq } \\
(\mathrm{F})\end{array}$ & $\%$ & & \\
\hline $\begin{array}{l}\text { Lecture } \\
\text { Referring Ppt. }\end{array}$ & 45 & 33.6 & 41 & 30.6 & 18 & 13.4 & 10 & 7.5 & 0 & 0 & 3.46 & 1 \\
\hline Audio-Video & & & & & & & & & & & & \\
\hline Based Teaching & 29 & 21.6 & 13 & 9.7 & 14 & 10.4 & 7 & 5.2 & 3 & 2.2 & 1.91 & 2 \\
\hline Case Studies & 9 & 6.7 & 19 & 14.2 & 20 & 14.9 & 12 & 9 & 11 & 8.2 & 1.61 & 3 \\
\hline $\begin{array}{l}\text { Lecture } \\
\text { Referring Book }\end{array}$ & 10 & 7.5 & 10 & 7.5 & 15 & 11.2 & 9 & 6.7 & 6 & 4.5 & 1.19 & 4 \\
\hline Quiz & 6 & 4.5 & 11 & 8.2 & 9 & 6.7 & 15 & 11.2 & 15 & 11.2 & 1.09 & 5 \\
\hline Dictating Notes & 10 & 7.5 & 15 & 11.2 & 8 & 6 & 2 & 1.5 & 5 & 3.7 & 1.07 & 6 \\
\hline Project Work & 7 & 5.2 & 9 & 6.7 & 12 & 9 & 11 & 8.2 & 8 & 6 & 1.02 & 7 \\
\hline Brainstorming & 5 & 3.7 & 5 & 3.7 & 6 & 4.5 & 9 & 6.7 & 11 & 8.2 & 0.69 & 8 \\
\hline Field Visit & 4 & 3 & 2 & 1.5 & 2 & 1.5 & 4 & 3 & 4 & 3 & 0.34 & 9 \\
\hline Demonstration & 3 & 2.2 & 1 & 0.7 & 1 & 0.7 & 1 & 0.7 & 2 & 1.5 & 0.19 & 10 \\
\hline Total & 128 & 95.5 & 126 & 94 & 105 & 78.3 & 80 & 59.7 & 65 & 48.5 & & \\
\hline
\end{tabular}

From Table 3, it is seen that majority of the students find lectures using power point presentations as the most easy to recall, followed by audio video based teaching and case studies method. On the contrary, they find demonstration, field visit and brainstorming (group discussion) as the most difficult to recall.

Table 3

\section{Students' Perception on the Ease to Recall the Lessons Learnt Using Different Pedagogies}

\begin{tabular}{|l|l|l|l|l|l|l|}
\hline \multirow{2}{*}{} & \multicolumn{3}{|c|}{ Students' Perception on Ease of Recalling Lesson Learnt Using Different Pedagogies } & \\
\cline { 2 - 6 } & Most Easy (5) & $\begin{array}{l}\text { Moderately } \\
\text { Easy(4) }\end{array}$ & $\begin{array}{l}\text { Easy } \\
(3)\end{array}$ & $\begin{array}{l}\text { Difficult } \\
(2)\end{array}$ & $\begin{array}{l}\text { Most Difficult } \\
(1)\end{array}$ & \\
\hline
\end{tabular}




\begin{tabular}{|l|c|c|c|c|c|c|c|c|c|c|c|c|}
\hline $\begin{array}{l}\text { Types of } \\
\text { Pedagogy }\end{array}$ & $\begin{array}{c}\text { Freq } \\
(\mathrm{F})\end{array}$ & $\%$ & $\begin{array}{c}\text { Freq } \\
(\mathrm{F})\end{array}$ & $\%$ & $\begin{array}{c}\text { Freq } \\
(\mathrm{F})\end{array}$ & $\begin{array}{c}\text { Freq } \\
(\mathrm{F})\end{array}$ & $\begin{array}{c}\text { Freq } \\
(\mathrm{F})\end{array}$ & $\begin{array}{c}\text { Weighted } \\
\text { Mean }\end{array}$ & Rank \\
\hline $\begin{array}{l}\text { Lecture } \\
\text { Referring Ppt. }\end{array}$ & 19 & 14.2 & 32 & 23.9 & 25 & 18.7 & 9 & 6.7 & 2 & 1.5 & 2.37 & 1 \\
\hline $\begin{array}{l}\text { Audio-Video } \\
\text { Based Teaching }\end{array}$ & 35 & 26.1 & 9 & 6.7 & 12 & 9 & 4 & 3 & 2 & 1.5 & 1.92 & 2 \\
\hline Case Studies & 16 & 11.9 & 16 & 11.9 & 17 & 12.7 & 6 & 4.5 & 8 & 6 & 1.60 & 3 \\
\hline Quiz & 13 & 9.7 & 13 & 9.7 & 10 & 7.5 & 13 & 9.7 & 13 & 9.7 & 1.39 & 4 \\
\hline Project Work & 7 & 5.2 & 19 & 14.2 & 13 & 9.7 & 9 & 6.7 & 4 & 3 & 1.28 & 5 \\
\hline Dictating Notes & 15 & 11.2 & 10 & 7.5 & 5 & 3.7 & 3 & 2.2 & 3 & 2.2 & 1.04 & 6 \\
\hline $\begin{array}{l}\text { Lecture } \\
\text { Referring Book }\end{array}$ & 9 & 6.7 & 4 & 3 & 11 & 8.2 & 10 & 7.5 & 7 & 5.2 & 0.90 & 7 \\
\hline Brainstorming & 8 & 6 & 5 & 3.7 & 5 & 3.7 & 9 & 6.7 & 9 & 6.7 & 0.76 & 8 \\
\hline Field Visit & 2 & 1.5 & 7 & 5.2 & 3 & 2.2 & 5 & 3.7 & 2 & 1.5 & 0.44 & 9 \\
\hline Demonstration & 3 & 2.2 & 1 & 0.7 & 0 & 0 & 0 & 0 & 2 & 1.5 & 0.16 & 10 \\
\hline Total & 127 & 94.7 & 116 & 86.5 & 101 & 75.4 & 68 & 50.7 & 52 & 38.8 & & \\
\hline
\end{tabular}

In table 4 , since the p-value is less than 0.05 , it can be concluded that there is significant relationship between ease of understanding the pedagogy and its effectiveness.

Table 4

Chi-square Tests of Most Easy to Understand and Most Effective Pedagogy

\begin{tabular}{|c|c|c|c|}
\hline & Value & Df & P-value \\
\hline Pearson Chi-Square & $6.042 \mathrm{E} 2 \mathrm{a}$ & 144 & 0 \\
\hline Likelihood Ratio & 232.15 & 144 & 0 \\
\hline
\end{tabular}

From table 5, we can see that the p-value is less than the level of significance 0.05 which indicates that there is significant relationship between ease to recall the lessons learnt using the pedagogy and effectiveness of that pedagogy.

Table 5

Chi-square Tests of Most Easy to Recall and Most Effective Pedagogy

\begin{tabular}{|l|c|c|c|}
\hline & Value & Df & P-value \\
\hline Pearson Chi-Square & $4.302 \mathrm{E} 2 \mathrm{a}$ & 156 & 0 \\
\hline Likelihood Ratio & 172.825 & 156 & 0.169 \\
\hline
\end{tabular}




\section{Suggestions by the Students}

When asked about what other methods of pedagogies besides what is being used currently should be applied by their teachers, the students suggest as follow:

a) Field visit till date are not that effective. To take advantage of this method, more effective and planned market/field visit should be organized. It is one of the best methods to gain practical experience of the theory taught in class and also has a close look at what they have to face in real world and how to tackle those situations/challenges.

b) Breaking monotony by mixing different pedagogies like interactive methods and games should be encouraged. Games should be integrated in the course since its fun and easy to recall.

c) Role play helps to get practical real life situational analysis, so it should also be integrated while teaching.

d) Practical problem solving simulations can be useful in real life for the survival in the competitive environment. Practical learning should be focused more than theoretical knowledge since learning by practicing is easier to understand and recall.

e) Case studies of real businesses and real world examples should be used while teaching. Also, case studies followed by class discussion are more productive.

f) Guest lectures by professionals related to the course/subjects can be an added resource of better learning.

\section{Faculties Perceptions on Different Pedagogies}

It was found that the faculties were currently using power point presentations, case study method, group discussions on relevant problems or topics, company visit, audio video and research methods. They think the most effective teaching methods are case based and group discussion method where the students can critically think about the solutions to the problems by brainstorming among the team members; while the least effective methods are dictation, lecture referring books and power point slides since these could be monotonous at times and with less interaction the students get bored and lose the attention easily.

The faculties seemed eager to try their hands on innovative teaching pedagogies like simulation, field work, research based techniques and also role play techniques. They wanted to use these new techniques to evoke interest in students, provide real life scenario, to encourage more out of the box thinking, to upgrade their self- knowledge and also to be updated and meet the global standards. Some of the factors that cause the faculties to not use these innovative pedagogies 
until now are they being less tech savvy, lack of infrastructure support, lack of institutional support and the quality of the students.

\section{Suggestions by the Faculties for Development of Better Teaching-Learning Environment}

a) More focus on real life based teaching rather than theory based teaching.

b) Faculties should be empowered to create an environment where the students get interested and encouraged to try on the new pedagogies and curious to visit the field and understand the real work life.

c) Faculties should be provided with training on utilizing different innovative pedagogies to enhance their teaching skills.

d) Proper application of research based pedagogy is one of the options for excellence of learning in academic institution.

e) Institution should make better and updated technology available in order to create better teaching learning environment.

\section{Conclusion}

It can be concluded from this study that there is a slight difference as well as similarity in how the student and faculty members perceive the different teaching pedagogy being asked to them. The students perceive lecture using power point presentations as the most effective one followed by case studies and audio video teaching methods whereas demonstration, field visit, dictating notes and brainstorming (group discussion) as the most ineffective pedagogies. Students also perceive lecture using power point presentations followed by audio video based teaching as the most easy to understand as well as recall. On the contrary, the faculties perceive case based and brainstorming/group discussion method as the most effective teaching methods, while the least effective methods are dictating notes, lecture referring books and power point slides. It is also found that there is significant relationship between ease of understanding the pedagogy and effectiveness of that pedagogy as well as between ease to recall the lessons learnt using the pedagogy and effectiveness of that pedagogy.

The outcome of this study indicates that the top reasons which act as hindrance for using any innovative teaching pedagogy as given by all the faculties are being less tech savvy, lack of infrastructure support, lack of institutional support and the quality of the students. This calls for faculty training programs to update them with use and application of new technology. The management of the college should also realize the importance of providing organizational 
support for the usage of various teaching pedagogies and the students should be encouraged to accept various teaching pedagogies since it boosts their learning process.

In order to enhance the teaching learning process in the management field, real life case study based on Nepalese business houses or organization should also be developed by the faculties and introduced in the course outline so that the students can get a hint of real life business problems faced by Nepalese businesses and be ready to tackle these challenges and solve them using their management and analytical skills that they learn in their classroom. Theoretical and practical learning should go hand in hand.

\section{Limitations and Direction for Further Study}

This study utilized few pedagogy methods and focused only on the students and faculties of Nepal College of Management, Dhobighat, Nepal. Some other variables like ease to apply, effective in enhancing subject knowledge, effective in providing problem solving skills and effective in evaluating the outcome might be more useful in order to explain the effectiveness of the different pedagogies which have not been employed in this study.

Different management colleges can conduct this research individually and also collectively utilizing different pedagogy techniques to find out the most effective pedagogies in their field of study and reform their pedagogy system accordingly. Educational institutions and universities of different fields other than management can also further conduct this study to find out the most effective pedagogy for their field of study taking more sample size of both students and faculties. Some other tools may also be used in order to find the views and opinions of the respondents.

\section{REFERENCES}

Ginsburg, M. B. (2010). Improving educational quality through active-learning pedagogies: A comparison of five case studies, Educational Research, 1(3), 062-074.

Goyal, E. \& Parekh, V. (2012). Comparison of Various Pedagogies in Management Education, Indian Journal of Higher Education, Vol.3, No.2.

Kozma, R.B. (2003). Technology and Classroom Practices: An International Study, Journal of Research on Technology in Education, Vol. 36, No. 1. 
Kumar, K. (2014). A Relook into Teaching Pedagogy in Management Education, Electronic copy available at: http://ssrn.com/abstract=2391288.

Narayandas, N., Rangan, V. K. and Zaltman, G. (1998). The Pedagogy of Executive Education in Business Markets, Journal of Business-to-Business Marketing, Vol. 5(1/2).

National Board for Professional Teaching Standards (1998), Washington, DC. Retrieved on: June 22, 2016, Retrieved from: http://www.nbpts.org/

National Business Education Association (2004). This We Believe about Business Education in a Global Environment, Electronic copy available at: https:/www.nbea.org/ newsite/ curriculum/policy/no_74.pdf

Nawaz, N.M. \& Gomes, A.M (2014).An Effective Teaching Pedagogy in Changing Business Education, Journal of Education and Practice, ISSN 2222-1735 (Paper) ISSN 2222288X (Online), Vol.5, No.19.

Raman, A. (2013). Innovative Pedagogical Methods for Imparting Management Education to Indian Students, International Journal of Computing, Communications and Networking, ISSN 2319-2720, Vol 2, No.4.

Watkins, C. and Mortimer, P. (1999). Pedagogy: What do we know? In Mortimer P (Ed), Understanding pedagogy and its impact on teaching, pp. 1-19, London: Chapman.

Whitby, G.B. (2007). Pedagogies for the 21st Century, ACEL 2007 International Conference, Sydney, Australia, Electronic copy available at: https://robertsonss.eq.edu.au /Supportandresources/Formsanddocuments/Documents/pedagogy-for-the-21stcentury.pdf. 